(23)

ポリエステルー分散染料糸の高温での二色性

\author{
東京都立大学工学部 中山 和 郎・岡 島 三 郎 \\ 小林 靖三
}

\title{
DICHROISM OF POLYESTER-DISPERSE DYE SYSTEM AT HIGH TEMPERATURE
}

By Kazuo Nakayama, Saburo Okajima and Yasuji Kobayashi

(Faculty of Technology, Tokyo Metropolitan University, Setagaya-ku, Tokyo, Japan)

The visible dichroism (D) of poly (ethylene terephthalate) film dyed with C.I. Disperse Yellow 7 or C.I. Disperse Red 17 was measured at $20 \sim 180^{\circ} \mathrm{C}$. and the temperature effect on D was investigated. For this purpose a spectrophotometer equipped with a specially designed heating cell was used. Dyed PET films were prepared in two ways: (A) Undrawn film was dyed $\left(70^{\circ} \mathrm{C} ., 20 \mathrm{hr}\right.$. and then drawn $\left(68^{\circ} \mathrm{C}\right.$.), and (B) Undrawn film was drawn $\left(57\right.$ or $68^{\circ} \mathrm{C}$.); heat-treated $\left(190^{\circ} \mathrm{C}\right.$.) and then dyed $\left(130^{\circ} \mathrm{C} ., 90 \mathrm{~min}\right.$.).

The results are following:

(1) The measurements of D at elevated temperatures could be carried out as accurately as in the usual measurement at room temperatures.

(2) D decreases linearly as the temperature is elevated. In the case of films which have never been heat-treated above $120^{\circ} \mathrm{C}$, two inflection points appear on heating in the relation $\mathrm{D}$ vs temperature at $80^{\circ} \mathrm{C}$, and $120^{\circ} \mathrm{C}$, and the change of $\mathrm{D}$ with temperature is irreversible, whereas in the case of films previously subjected to heat-treatment above $120^{\circ} \mathrm{C}$, D changes reversibly when the temperature of the fllm remains below the temperature of treatment and the inflection point at $80^{\circ} \mathrm{C}$. can hardly be observable.

From this phenomenon it is concluded that $\mathrm{D}$ of the heat-treated or thermally contracted PET, measured even at room temperature, indicates correctly the degree of amorphous orientation of polymer changed through the treatment and the intrinsic dichroism of the dyed polymer remains constant. As to the $120^{\circ} \mathrm{C}$. inflection point, it is attributed to another transition point of the amorphous region remaining in PET after the cold crystallization.

(Received December 25, 1967)

\section{1. 粕}

\section{言}

ポリマーの非晶領域の配向を知る一つの方法として可

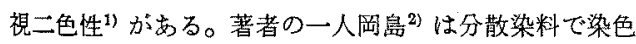
したポリエステル織維（テトロン）を熱収縮させると， 熱収縮後の室温での二色性配向度 $f_{D}$ がいちじるしく低 下し，收縮率の対数 $\log S$ を絶対温度の近数 $1 / T$ K対し てプロットしたときの曲線にあらわれる属曲点に相当す る温度に $f_{D}$ の変化る対応していることから，ポリマー の非晶領域の配向度と取縮との間には密接な関係がある と報告した。まなポリアクリロニトリルについて子同様 なことが認められだ。
このとき，高温処理による $f_{D}$ の低下は，もっばらポ リマーの配向度低下と考えたが，この程度の温度で，染 色した織維を堿圧下に和くと染料が瀻維より昇華してく ることがわかったので，染料分子がポリマ一鎖より遊 離しても，室温汇泠却すればまた元の結合状態にもど りホポリーの配向度が不变ならば，加熱前と等しい $f_{D}$ を示すのか，むるいはポリマーの配向度と無関係に $f_{D}$ が低下するのかを検討することが必要になった。しかる 高温の $f_{D}$ に関する検討が今までになされていないので， 本報でこれを行なった。その結果は高温に拉ける染着分

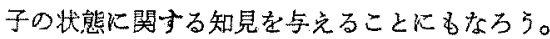




\section{2. 寒 験 法}

\section{$2 \cdot 1$ 碔料フィルム}

テトロン（ポリエチレンテレフタレート）未延伸フィ ルムを試料とした。厚さは約 $50 \mu$ で，汪汪等方質，非 晶質であった。

\section{$2 \cdot 2$ 染色 法}

染料は C.I. Disperse Red 17 (モノアゾ系) と，いく ぶん昇華しやすい，C.I. Disperse Yellow 7 (ジスアッ゙ 彩をを牨のおのタノール・水，アセトン・水で精製し て用いた（以後，扣の扮の染料 I, 染料正と略記)。

染料 I C.I. Disperse Red 17

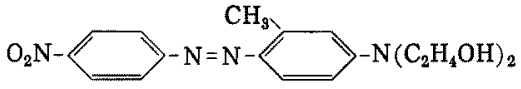

染料 II C. I. Disperse Yellow 7

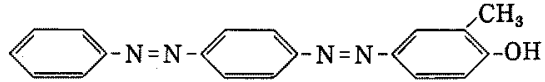

未延伸ポリエステルフィルムは $70^{\circ} \mathrm{C}$ で 20 時間染色 した後、フィルム表面に付着した染料をかタノールで洗 い落した。聚張熱処理（熱固定）ポリエステルフィルム は， $130^{\circ} \mathrm{C}$ で 90 分間染色後，アセトン・水 $(1 ： 1)$ で洗った。

\section{$2 \cdot 3$ 延伸・熱処理}

$2 \cdot 2$ に上る末延伸染色フィルムを $68^{\circ} \mathrm{C}$ の温水中にフ イルムの温度が一定になるまで 10 分間浸せさし, 浴中 で手動延伸機を用いて延伸した。延伸後は室温で泠却し て，45 分後に延伸機からはずした。

緊張熱処理（熱固定）試料用の未染色フィルムも同様

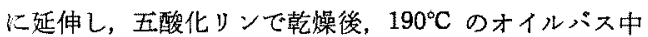
で5分間爇処理して，2.2 によって染色した。

\section{$2 \cdot 4$ 二色性測定法}

延伸軸（配向軸）方向とそれに直角方向に振動する腐 光の陚料フィルムを通過した強さの变化から吸光度 $K_{\text {II }}$ ， $K_{\perp}$ 它得，（1）式加的色性值 $D$ を求める。

$$
\begin{aligned}
D & =\frac{K_{\|}-K_{\perp}}{K_{\|}+2 K_{\perp}} \\
& =\frac{R-1}{R+2}
\end{aligned}
$$

ここでRは二色此すなわる $R=K_{\|} / K_{\perp}$ である。

$$
f_{D}=\frac{D}{D_{0}}
$$

観測した二色性值 Dから，複屈折からの配向度に対応す る配向度を(2) 式から求めるためКは完全配向で $f_{D}=1$ の二色性值 $D_{0}$ 妾知る必要があるが，本報では $D_{0}$ の值 にはふれないで，Dの温度変化で検討する。

室温での二色性の測定は常法ら)で行なった。浸せき液
としてトリクレジルホスフェートを用い, 紫外可視分光 光度計（日立 EPU-2 A 型）に㽾光板をとりつけて行な った。リファレンスとして同じ処理をした末染色フィル ムを使い，染色フィルムの吸光度 $K_{\|} ， K_{\perp}$ を最大吸収ピ 一クより長波長側の適当な波長で数点測定し，その $K_{\|}$, $K_{\perp}$ を直交莝標にとって得られた面線の傾きから二色比 $R$ を得て，(1)式からDを算出した。

高温に叔ける三色性の测定の原理は室温の場合と同し であるが，赤外吸収スベタトル用の加熱水平をルを分光 光度計のセルホルダーの位置にとりつけて行なった。こ の場合，浸せき液が使えないので，慎重な測定をする必 要があった。加熱水平七ルには $45^{\circ}$ 储いた金属ミラーを 4 枚使用してかり，偏光の電気ペクトルの方向によって 反射の効率が異なるので，ミラー面と振動力何とは常に 平行になるよ5に仳光板を固定し，試料フィルムを回転 し，延伸方向と编光の電気べクトルが一致执よび直交す るように扣いて测定した。測定の際には，室温から温度

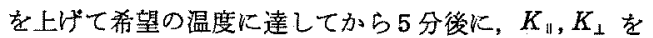
測定し，再び温度を上げる操作をくり返した。二色性測 定の際には，試料フィルム中央の温度は㵋定できないの で, 加熱炉の温度を測り，加熱炉と試料中央の温度補正 曲線によって，それを算出した。

\section{3. 実験結果および考察}

\section{$3 \cdot 1$ 常法による二色性測定と加熱水平セルを用いた 場合の比較}

装䈯の検定のために同一試料フィルムの二色性を常法 で測定した結果 $(D)$ と，加熱水平セルを用いて室温で测 定した結果 $\left(D_{h}\right)$ とを比較検討し，それを図1に示す。 加熱水平セルを用いた場合には浸せき液が使えないが， フィルム表面での反射，干渉による愦差考虑してむよ く一致している。そこで以下の結果では加熱水平をルを

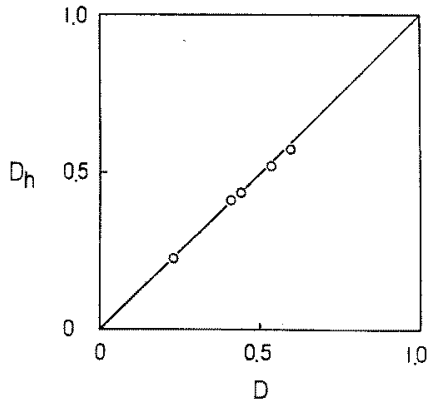

Fig. 1. Comparison between dichroism obtained by usual method (D) and the one obtained at room temperature with the heating cell $\left(D_{h}\right)$. 


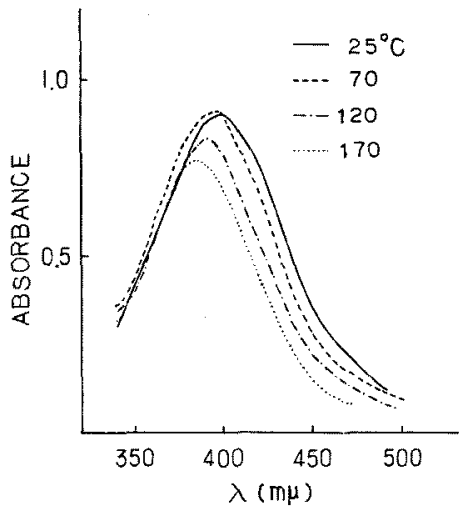

Fig. 2. Spectra of C. I. Disperse Yellow 7 in poly (ethylene terephthalate) film at different temperatures.

用いた測定值をDとする。

\section{2 高温での吸収スペクトル}

延伸後に熱処理した試料フィルムを染料匹で染色し， 高温で二色珄スペクトルを測定した。吸光度の平均值， $K_{\mathrm{iso}}=\left(K_{\sharp}+2 K_{\perp}\right) / 3$ をプロットしたのが図 2 である。 吸収スペクトルは温度が高いはど短波長側にシフトし， また吸光度も減少する。しかし，室温にもどすと吸収ス ベクトルは䒜温前のスペクトルと一致する。変化が温度 に対して可逆的であることから，この程度の温度では染 料は安定であると思われる。この温度による最大吸収ピ 一クの短波與側へのシフトは今のところ原因は，はっき

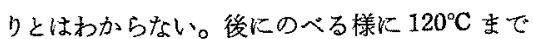
永リマーの配向度の変ら奴と考えられる場合に

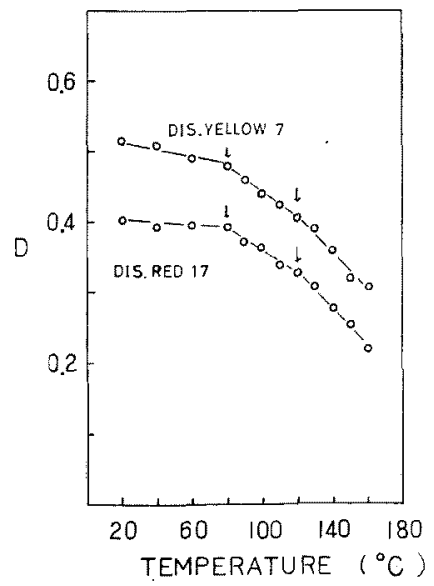

Fig. 3. Change in dichroism $D$ of dyed film with temperature.
はDの值も変らぬと諗められるから， $D_{0}$ が温度によっ て変ると考えないでよいである5。以下 $D_{0}$ を一定とし て考察する。

\section{$3 \cdot 3$ 高温での二色性値の変化}

三種の染料で染色し延伸したポリエステルフィルムの 二色珄の温度变化を図 3 亿示す。二色珄值 $D$ は温度上昇 により直線的に減少しているが，80 $\mathrm{C} 120^{\circ} \mathrm{C}$ 付近に 屈曲をるち，雨者はほほ平行に变化している。この変化 は染料の種類によらずポリエステルの非晶領域の挙動を よくあらわしていると考光られる。な拈，二色性值が染 料によって翼なるのは固有二色性 $D_{0}$ の違いによるるの である。

さらにくわしく調べるために，染料IIで染色し 4.7 倍 延伸したポリエステルフィルムの二色性值の温度变化を しらべた（図 4)。試料フィルムは縮京ないよ5に固定 し，定長のままで室温から温度をあげてゆくと，二色性 値Dはわずかずつ低下し，80

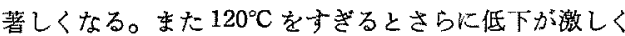
なる。 $80^{\circ} \mathrm{C}$ の屈曲点は一般にいわれているガラス転移 点に相当する。この温度より高温ではポりマーの非晶領 域のミタロブラウン運動が括こり, 主としてポリマーの 配向度低下により観察する二色性が低くなる。120 も属曲がみられる。この温度付近から低温結晶化が進も ことはよく知られており ${ }^{6)}$ ，低温結晶化にとるなって非 晶領域の配向度低下が生じているのであるう。次に， $160^{\circ} \mathrm{C}$ 付近から盜度を下げると，二色性值はわずかずつ

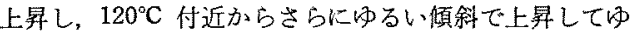

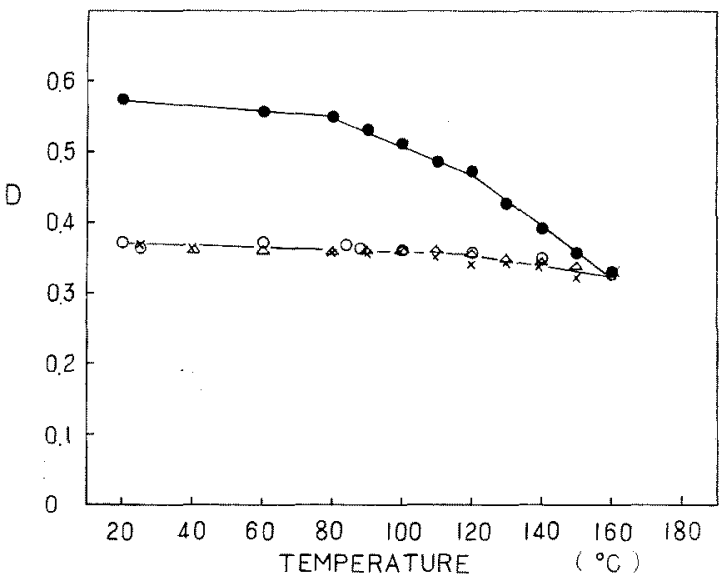

Fig. 4. Change in dichroism $\mathrm{D}$ with temperature. Film was dyed and stretched.

- First heating $\bigcirc$ First cooling $\times$ Second heating $\triangle$ Second cooling 


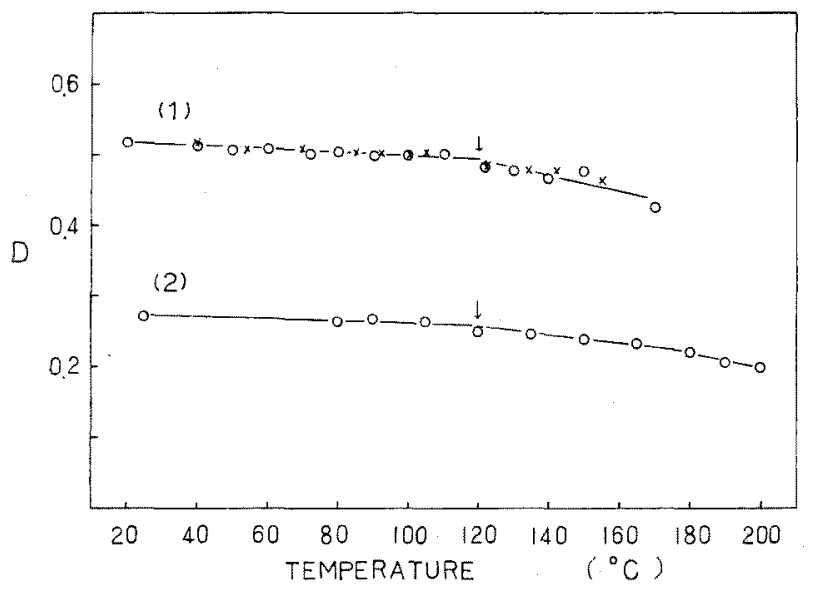

Fig. 5. Change in dichroism $\mathrm{D}$ with temperature. Films were stretched, heat-treated and dyed. heating, $x$ cooling

\begin{tabular}{c|c|c|c}
\hline & stretching & heat-treatment & dyeing \\
\hline (1) & $57^{\circ} \mathrm{C} ., 4.5 \times$ & $190^{\circ} \mathrm{C} ., 5 \mathrm{~min}$. & $130^{\circ} \mathrm{C} ., 90 \mathrm{~min}$. \\
(2) & $68^{\circ} \mathrm{C} ., 4.5 \times$ & $190^{\circ} \mathrm{C} . .5 \mathrm{~min}$. & $130^{\circ} \mathrm{C} ., 90 \mathrm{~min}$. \\
\hline
\end{tabular}

られる。したがって最初の昇温過程では $120^{\circ} \mathrm{C}$ 付近からの著しい二鼠性の低下は， 主として低温結晶化による非晶の配向度低 下と考党られるが，それ以後の昇温または 降温過程での可逆的屈曲は残っている非昆 部分の転移と考元られる。 $120^{\circ} \mathrm{C}$ 火非毘の 転移点があることは一般には，考えられて いないか゚，Hellwege らすは結晶化磨をか えたポリエチレンテレフタレートで詳細に ディラトメトリーを行ない, いわ妇る゙゚ラ ス転移点の活かに $120^{\circ} \mathrm{C}$ 辺に属曲点を観察 している。また土谷らはNMRにより二 つの転移を観察している。

次に延伸緊張熱処理後に染料 II で染色乙 た試料についての二色性の温度変化を图 5 に示す。 $57^{\circ} \mathrm{C}$ (1) と $68^{\circ} \mathrm{C}$ (2)で 4.5 倍延

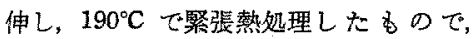
(1)が(2)上り配向度は高い。この二色性 值の温度変化は $120^{\circ} \mathrm{C}$ 火屈曲点をるち, $190^{\circ} \mathrm{C}$ にすでに加熱されているのて，む忧 や $120^{\circ} \mathrm{C}$ 付近の低温結晶化は起らず，実験

くっこの試料片を再び温度の上昇、下降をくりかえす そ, 以後可逆的に変化する。このこそから $80^{\circ} \mathrm{C}$ のガラ ス転棃点とは別の非晶部分の転移が $120^{\circ} \mathrm{C}$ にあると考え

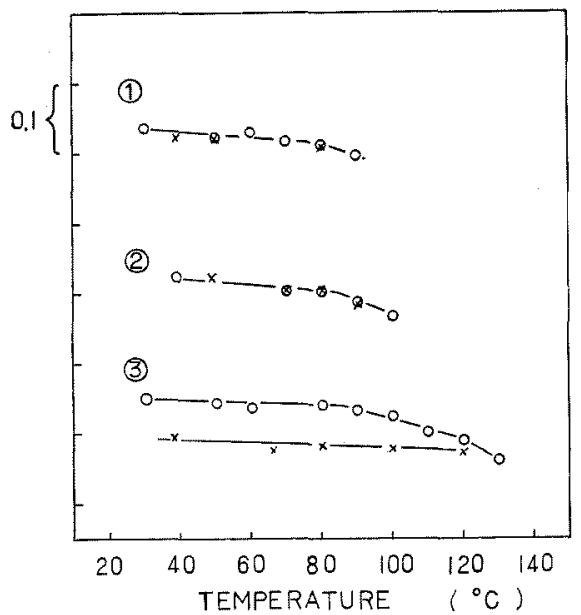

Fig. 6. Change in dichroism of a specimen during the heating and cooling cycles. $O$ heating $x$ cooling

(i) First cycle (up to $90^{\circ} \mathrm{C}$.)

(2) Second cycle (up to $100^{\circ} \mathrm{C}$.)

(3) Third cycle (up to $130^{\circ} \mathrm{C}$.)

(1) (3) are shifted down one by one in order to avoid overcrowding.
の範囲の温度ではDの変化は可逆的である。变化が可逆 的であることから染料が一時的にポリマーの非晶鎖から 離えることがあってる，あまり激しい移動はないと考克

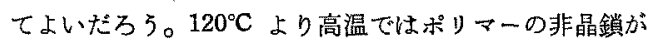
熱運動によって，凍結された位置からずれることによ。 て钼察される二色性値が低くなるるのと思われる。8 $80^{\circ} \mathrm{C}$ に属曲がみられないのは，結晶化度が高いことで，非晶 領域の量の減少と非晶銧が結晶に拘束されて熱運動性が 減少し，この二色性の温度変化には，はっきりあらわれ

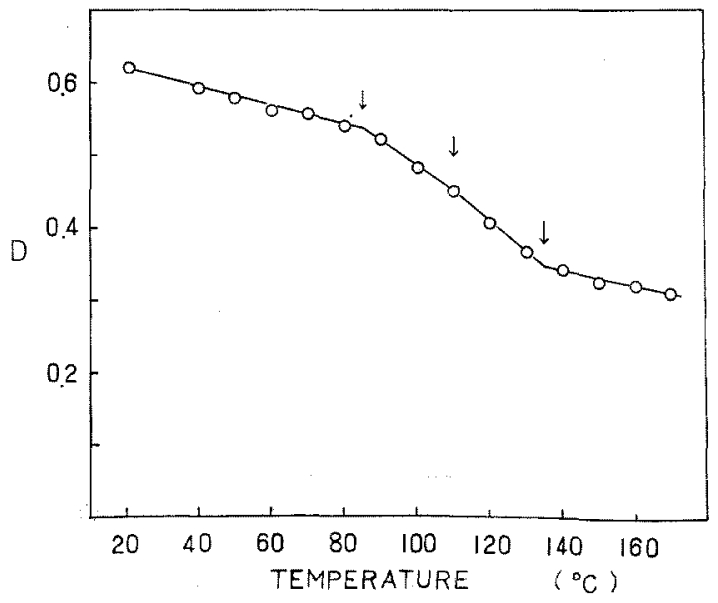

Fig. 7. Change in $\mathrm{D}$ during thermal contraction. 
てこないと考えられる。 $80^{\circ} \mathrm{C}$ の転移点が $120^{\circ} \mathrm{C}$ に上昇 したのではないことは，すでにのべた Hellwege や土 谷・山惪の実験のみならず，著者らによってもジラトメ

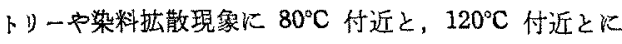
2 この転移が明り上5に認められるからである。これら については別に報告する。

結晶化の影每をたしかめるために染色後延伸した同一 陚料フィルムをくり返し界温して，その時の最高温度を 順に $90 ， 100 ， 130^{\circ} \mathrm{C}$ まで高め，二色性の温度变化を測 定したのが図6である。90ㄷ $100^{\circ} \mathrm{C}$ まで昇温 (2) の過程) では， $80^{\circ} \mathrm{C}$ 付近江屈曲

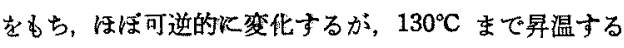
と $120^{\circ} \mathrm{C}$ にる屈曲があらわれて，その降温過程ではもは

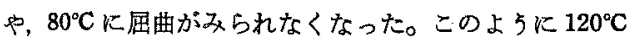
より高温にして，ある程度結晶化がすすむと， $80^{\circ} \mathrm{C} の$ 転移はこの方法では観察されなくなる。

\section{4 熱収 䑿}

図3〜目6では試料を定長に保って測定したが，高配 向試料を自由に収縮するようにして昇温しながら二色性 を湖定したのが图 7 である。この場合には、 $85^{\circ} \mathrm{C}, 110$ ${ }^{\circ} \mathrm{C}, 135^{\circ} \mathrm{C}$ 付近飞屈曲点をるつ。图 4 と比べると収縮を 伴な5場合は $85^{\circ} \mathrm{C}$ までの二色性の低下むわり岕い大き くそそい後の低下も著しい。

\section{4. 結 論}

（1）加熱炉を使用しても定量的に二色性が测定でき
（2）高温でのポリエステル—分散染料系の二色珄 の変化はポリマーの非晶領域の举動をよくあらわす。

(3) $80^{\circ} \mathrm{C}$ のガラス転移点のはか子 $120^{\circ} \mathrm{C}$ 付近にむ。 非晶の転移がある。

（4） ポリエステルの配向度の变ら奴簙围では $D$ は可 逆的湾化し，非晶鎖から高温で染料が一時的㷰隹れる ことがあっても，あまり激しい移勘はなく，降温により 元の状態にも゙る。

（5）従来，染色ポリエステル瀻維で括こなわれてき た熱処理，あるいは熱收縮後の二色性配向度の室温での 測定值は, 非晶領域の挙動と, その配向度をよく劣らわ しているといってよい。

(昭和 42 年 10 月, 緎維学会秋季研究発表会て発表)

本研究をなすにあたり，試料ポリエチレンテレフタレ ートフィルムを笴贈された帝人株式会社桜田健二専務に 深謝する。

\section{文献}

1）たとえば 网島三郎；高分子，15，862 (1966)

2）岡島三郎，矢尾欣次；緒学誌，22，17 (1966)

3）岡島三郎，松尾俊二; 縄学誌, 22, 14 (1966)

4) 岡島三郎，岡田鶴子，柴田二三男; 縺維学会昭和! 42年春期研究発表会講演要旨集, p. 2

5）岡島三郎，小林靖二; 染色工甞，12，651（1964）

6) B. Ke ; J.Appl. Polymer Sci., 6, 424 (1962)

7) K. H. Hellwege, J. Henning and W. KnappeKolloid-Z, 186, 29 (1962)

8）土谷敏雄，山累恭造；第 15 回高分子討論会講演: 要旨集，p, 81 る。 